総説

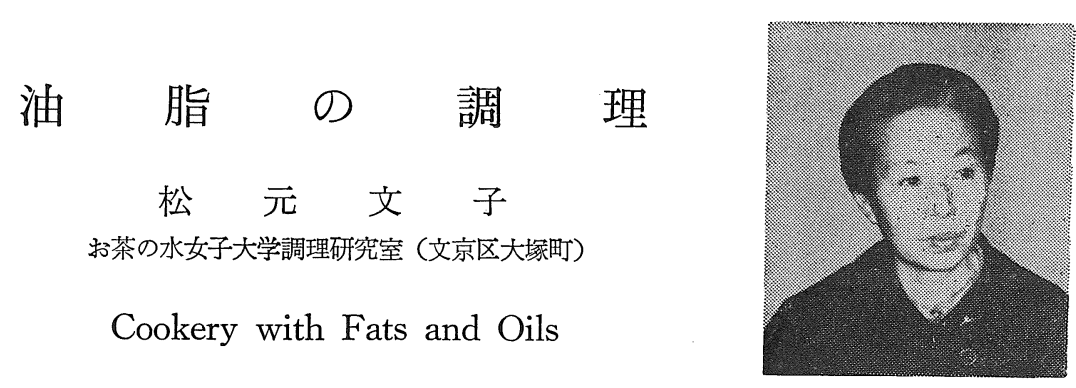

\title{
Fumiko Matsumoto
}

Ochanomizu Women's University, Department of Food, Faculty of Home Economics (Ōtsuka-chō, Bunkyō-ku, Tokyo)

\section{1 油脂の調理性}

油脂を調理の立場からみるとその性質ははなはだ多方 面である。すなわち，油脂の調理性としてつぎのような ことがあげられる。

1. 加熱によって簡単に高温が得られる。

2. 水分を含まない。水と混ざらない。

3. 水より軽い。水より粘度が高い。

4. 乳化剤によってエマルションになる。

5. 固形脂は温度によってかたさが違い，さらに高温 になると液化し，温度が下がるとふたたび固体にな る。

6.クリーミング性がある。

7. ショートニング性がある。

8. 特有の油脂味がある。

天然の食品には多かれ少なかれ油脂が含まれるが，そ れが食品の一成分として食品中にあるときは，上のよう な調理性の多くはほとんど発揮されない。食品のほかの 成分もそれと同じことはいえるが，油脂は食品から抽出 精製されたとき，それが調理加工に利用されての効果が とくに大きいのは上の諸性質があるからであろう。

また，ナタネや米ヌカのように油を抽出しなければ食 品価值がないものもある。もっとも後に述べるように油 脂の諸性質は常に有効にのみ㗢くわけではなく，マイナ スになることもあって，調理技術の上で種々のくふらを 要する原因にもなっている。調理の実際において油脂が ぞのようにプラス，マイナスの面を表わすか，また，そ れに対して調理ではどのように処理しているかについて 述べてみたい。

\section{2 油脂の調理}

\section{$2 \cdot 1$ 揚 ザ 物}

この調理は油脂の調理性 1 を最も直接に利用したもの で，熱の媒体としての効果を称らった調理で使用温度は $200^{\circ} \mathrm{C}$ くらいまでであるから，煮物，蒸し物と比べて温 度範囲ははなはだ広く，伝導熱を主とするところから焼 き物より短時間で加熱の目的を達することができる。揚 げ物による油の変化については内外の有益な報告が多数 あるがここでは揚げ物による油の変化の問題には触れな いことにする。

油脂の調理性の 8 はすべての油脂調理において重要な ことではあるが，揚げ物ではとくに重要視される。油脂 味といってもよく精製された油では, 特徴のあるにおい ほほとんど感じられないで，口ざわりだけが油特有の粘 着性を感じさせる。サラダ油となると原料が何であるか がわかりにくい。このような油でてんぷらをすると淡白 すぎて物足りないといら人が多い。これにゴマ油を加え るとてんぷららしい味になって満足する。ここでてんぷ ららしい味というのはゴマのにおいである。油の味とは なめらかな口ざわりとにおいのことと考えてよいようで ある。

揚げ物は高温加熱のために食品からの脱水がはなはだ しく，それと交代的に油は食品に吸着される。この意味 で揚げることは水と油の交代の場を作ることといえる。 もし食品中にデンプンのよらなコ（糊）化に水を必要 とする成分があるならば，コ化に要する水までをも取り 去られることは防がなければならない。また，コ化に要 する時間を与えなければならない。こうみるとイモ類の ようなものは揚げ物には向がな食品にみえる。それに もかかわらずイモが揚げ材料になるのは調理性の 8 ，才 なわち, 油の味が加わることによっておいしくなるから で抜糸地瓜（パスティクゥ）(サッマイモの素揚げに濃

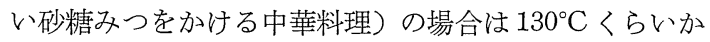

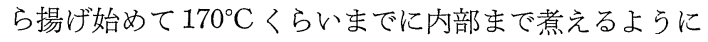
温度調節をする。それでも表面の一部は少し焦げてそれ がこの調理のおいしさの一つでもあるので, 切り方もそ れを期待して比較的大きい乱切りにする(乱切りは鋭角 の尖端が多い切り方である)。 
精進揚げにおけるサッマイモでは焦げを防ぐために， 衣を付けて揚げる。衣はイモのデンプンにコ化の時間を 与えるための脱水材料であり，結果として油を吸着した 衣はてんぷらのうま味に久くことのできないものであ る。 $1 \mathrm{~cm}$ くらいの厚さに切ったサッマイモの精進揚げ 法 $160^{\circ} \mathrm{C}$ から揚げ始好 $3 \mathrm{~min}$ くらいかけて $180^{\circ} \mathrm{C}$ 前 後で取り出せば, デンプンはコ化し衣の表面はからりと 乾いて，焦げもしない(これには衣の条件も関係する が)。揚げ物において油の温度調節は要点中の要点で, それは食品ごとに違うからとらてい簡単にはいいつくせ ない。

魚やエビの場合は生でも食べられる材料であるから， 揚げ時間はきわめて短くてよい。

一般に衣は材料から浸出するらま味を保つ役目と適度 に油と水と交代した衣自体の口ざわりのよさにある。揚 げ上がりの衣には 10\% 内外の水分は残っている方がか たすぎないでおいしい。この場合衣中の油はおよそ $40 \%$ 内外になる例が多いようである。

フライ、コロッケ，カツレツなどと呼ばれている揚げ 物は衣の焦げ味を楽しむものであるから，表面に乾物で あるところのパン粉を付けて高温の油で揚げ，その焦げ 色で揚げ終りとするから中実には加熱時間が短くてすむ ものでなければならない。

揚げ物の中には脱水を目的とするものもある。ポテト チップやクルトン，魚の素揚げなどがこれに属し，ポテ トチップやクルトンでは水分は 4〜 5\% くらいになるま で揚げられ，製品にほどよい焦げ色がつくように温度の 調節が行なわれる。ポテトチップではジャガイモは薄切 りにされているが，初めは低温で揚げデンプンがコ化さ れてから高温の油に移される, いわゆる二度揚げの方法 で揚げる。または塩水でゆでてから揚げる方法もある。 魚の場合はその後の調理法や保存期間に もよるから一概にはいえないが 30\% 以 上の水分を魚体中に残さないとうま味を 失う。

つぎにドーナツにおけるる油脂の功罪で あるが,この場合ドウ(dough)形成の一原 料として用いられる脂肪は調理性にあげ られた性質により，その柔軟性のために 小麦粉や砂糖，卵などとともにドーナツ の形を作ることができる。しかし，高温の 油で揚げられると脂肪はとけて流動性を 発揮し，ドウ中の脂肪量が多い場合は揚 げ油との交流が行なわれるからドーナツ の形は崩壊しようとする。これを防ぐの が小麦粉のグルテン形成, デンプンコ 化，卵の凝固などであるから，脂肪の融 解に先だってこれらがタイミングよく進
表-1 ドーナツ材料配合

\begin{tabular}{|c|c|c|c|c|c|c|c|c|c|c|c|}
\hline \multirow{3}{*}{$\begin{array}{l}\text { 実 } \\
\text { 験番 } \\
\text { 号 }\end{array}$} & \multicolumn{3}{|c|}{ 小麦粉 $100 \mathrm{~g}$} & べ. & ーキン & ノグー & ゚ウタ & ダーー 3 & & \multirow{3}{*}{$\begin{array}{l}\text { 製 } \\
\text { 嵒 } \\
\text { 盛 } \\
\text { 續 }\end{array}$} & \multirow{3}{*}{$\frac{S+F}{E}$} \\
\hline & \multicolumn{3}{|c|}{ 砂 $(\mathrm{g})^{\text {糖 }}$} & \multicolumn{3}{|c|}{$\begin{array}{c}\text { マーガリン } \\
(\mathrm{g})\end{array}$} & \multicolumn{3}{|c|}{ 卵 (g) } & & \\
\hline & 25 & $37.5 \mid$ & 50 & 5 & 10 & 15 & 10 & 22.5 & 35 & & \\
\hline 1 & 0 & & & 0 & & & 0 & & & 良 & 3.0 \\
\hline 2 & & 0 & & & 0 & & 0 & & & 可 & 4.8 \\
\hline 3 & & & 0 & & & 0 & 0 & & & & 6.5 \\
\hline 4 & 0 & & & & O & & & 0 & & & 1.6 \\
\hline 5 & & 0 & & & & 0 & & 0 & & 不 可 & 2.3 \\
\hline 6 & & & 0 & 0 & & & & 0 & & 不 可 & 2.4 \\
\hline 7 & 0 & & & & & 0 & & & 0 & 優 & 1.1 \\
\hline 8 & & 0 & & 0 & & & & & $\bigcirc$ & 優 & 1.2 \\
\hline 9 & & & 0 & & 0 & & & & 0 & 可 & 1.7 \\
\hline
\end{tabular}

○印は使用量の位置を示す

行するならば脂肪をドウ中に保持することができる。写 真は 表-1 の配合で行なわれたドーナツ実験 ${ }^{1{ }^{2}}$ の結果で 揚げ油の温度は常法に従い， $160^{\circ} \mathrm{C}$ からしだいに温度を 高くして $3 \mathrm{~min}$ で $180^{\circ} \mathrm{C}$ をむって揚げ終りとしたもの である。

実験 3 がまったく形を作らないのは脂肪の使用量が多 いことに加えて砂糖の量も多いからで, 砂糖もまた,ドー ナツ形成にマイナスに働くことは砂糖の性質から察せら

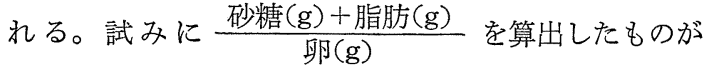
表の右列の数字で，大体これによってドーナツの成績を 予想することができる。しかし，この数字が大きいほど 製品はショートネスが大きくておいしい。そこで上に述 ベたタイミング調整のためにドウをあらかじめ冷蔵庫に 入れておくといら対策がある。

\section{$2 \cdot 2$ いため物}

いため料理は油が高温になりやすいこと，水と混合し ないことなどの性質を利用したもので，揚げ物に比べ少
No. 2

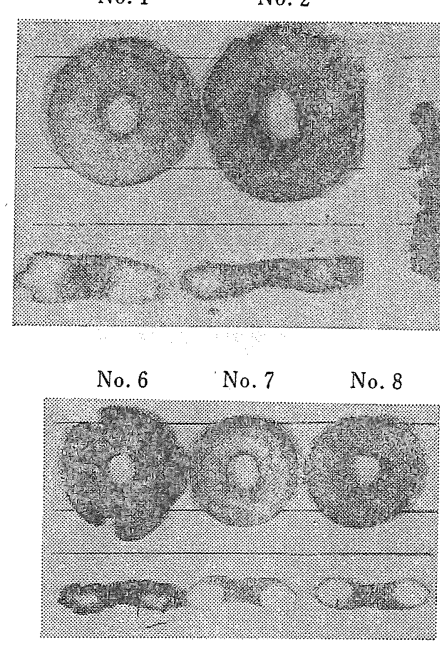

No. 3

No. 4

No. 5
図-1 ドーナッの成績 
量の油脂で油脂味が食品に加わることも，この調理が日 常よく行なわれる大きな理由の一つである。さらにま た, 残油の後始末がないこともこの調理が気軽に行なえ る理由であろう。

食品をいためる油の量は食品の成分や形などで異なる が，太田ら ${ }^{21}$ はキャベッ，豆モヤシ，卵，飯などのいた め実験で食品の重量の 5 〜 $10 \%$ の油の使用が適量であろ らと，また島田 ${ }^{3)}$ はみじん切りの玉ネギをいためるのに 油では 5 7\%，マーガリンでは 10\% までならば加熱時 間に関係なく残油はないと報告している。これらのいた め物では加熱温度が所要油脂量にも調理成績にも大きく 関与するわけであるが，揚げ物の場合と異なり，操作中 の温度測定はかなり困難であるう。太田らは線切りキャ ベツをいためる場合の温度を強火，中火，弱火としてな べ底, 中間, 表面について温度を測定している。それに よるとなべ底の最初の温度が $150^{\circ} \mathrm{C}$ でも $1 \mathrm{~min}$ の後に は $100^{\circ} \mathrm{C}$ 内外に下がる。いためにおいて食品の組織が こわれ，水分が浸出して絶えず蒸発するから，よほどの 熱を補わない限り温度の下がるのは防げないわけであ る。 $100^{\circ} \mathrm{C}$ 以下になれば温度において募物と同じことに なるからいためによる焦げ香は得られない。だからいた め物に扔いて焦げ香を必要とするならば初めの温度をは なはだ高くして食品からの浸出液が出る前に焦げ目をつ けるとか，あるいはまた，玉ネギのみじん切りいための ように食品からの浸出液はしだいに濃縮され蒸発水分が 少なくなるに従って温度が上がって焦げを生ずるという 経過をとることになる。島田の実験はいため時間ととも に変化する玉ネギの色，か扔り，味の変化を記録してい る。それによるとフライパン底の温度 $120^{\circ} \mathrm{C}$ で玉ネギ が加えられると油の種類と量に関係なく, $1 \mathrm{~min} く ら い ~$ で $90^{\circ} \mathrm{C}$ 内外まで温度が下がり, それ以後しだいに温度 は上がって $10 \mathrm{~min}$ の後には油の種類と量によって 150 〜 $190^{\circ} \mathrm{C}$ になって焦げ臭や苦味が生ずるという。

キャベツをいためるのと玉ネギをいためるのは目的が 違うから，いための終点も自ら違らわけである。

いためによる油の変化について太田は 5 min のいため は揚げ油 $200^{\circ} \mathrm{C} て ゙ 2 \sim 3 \mathrm{hr}$ に相当する，その理由はい ため物は油が薄層状態で加熱されるからであると述べて いる。

中華料理の炒溜菜では $30 \%$ 以上も油を使らことがあ る。これは残油が湯 (スープ) とともに最後にはデンプ ン汁とされることも計算に入れての上の使用油脂量と思 われる。この際, 調味液中にある油脂が完全にエマルシ ョンになるかどうかはわからないが，少なくともデンプ ンを加えないいため料理に比べて油脂味を直接に感ずる 度合は少ない。いため募の多い中華料理で油濃さを防ぐ 一つの方法として溜菜が考えられたものではなからう か。

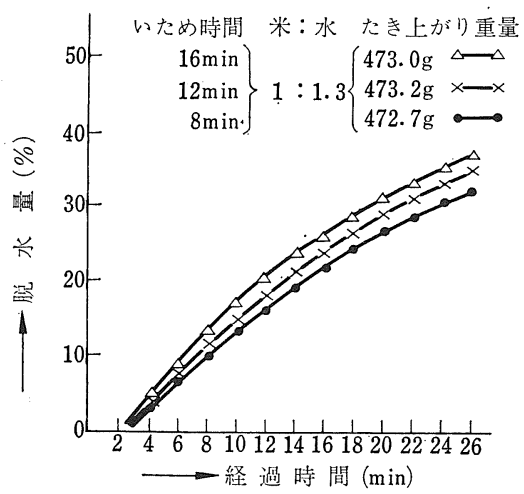

図-2 赤外水分計による飯の脱水速度

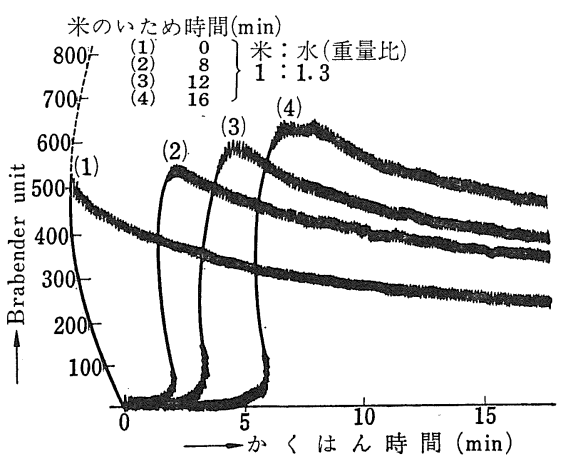

図-3いため飯の farinogram

表-2 いため米より抽出したバターの酸価

\begin{tabular}{|c|c|c|c|}
\hline \multirow{2}{*}{ 原料バタ一 } & \multicolumn{3}{|c|}{ いため時間 (min) } \\
\hline & 8 & 12 & 16 \\
\hline 1.26 & 4.73 & 5.18 & 5.85 \\
\hline
\end{tabular}

米のいため料理には，米をいためるものと飯をいため るものとがある。米をいためると米の組織がこわれるの で，これをたくといためない米より吸水が早いが，でき た飯の脱水も早い。図-2 はいため時間の違いによる飯 の脱水速度を示したもので，いため時間が長いほど脱水 が早い。

このような飯を farinograph にかけると図-3 のよう に，いため時間が長いほど飯はかたい4)。また，いため 時間が長いほど最高 B.U. に達するまでの時間が長い。 新米, 古米の比較研究 ${ }^{5}$ で古米は遊離脂肪酸が増してい るために新米に比べて飯がかたく，これが古米のまずい 原因の一つにあげられている。したがって，このような 米は普通の炊飯よりも加熱時間を長くする必要がある。 表-2 はバターでいためた米から脂質を抽出して，その 酸価を測定した実験の一例である。

なお，郷ら ${ }^{6)}$ は油脂を添加してたいた飯はデンプンの 老化が遅いと報告している。

炊飯の後に飯をいためる炒飯と呼ばれるものについて 
は, 現在実験中であるが，米は一応普通にたかれている から,デンプンのコ化については問題はないはずである。

一般にこの種の調理汇欧風料理では主としてバターを 用い，中華料理では豚脂が用いられてそれぞれ風味の上 で特徴づけられている。

小麦粉をバターでいためるルー（roux）は，小麦粉が 乾熱されるただ一つの調理であろら。風味をよくするた めに脂肪としてはバターが用いられるが，水分は小麦粉 のタンパク質に吸収されてグルテンを形成するからなべ にバターを最初に入れて溶かして，水分を蒸発させてか ら小麦粉をいためる方がよい。この意味では水分を含ま ない脂肪の方が適する。市販のカレールーではバターを 使っているものはほとんどなく,ケンネ油やその他の牛 脂が用いられているようである。

小麦粉が脂肪でいためられるとデンプンの一部はデキ ストリンとなって可溶性に変わるからスープやソースに する場合，まま粉になるのを防ぎ，タンパクはグルテン 形成をしにくくなる。また，小麦粉成分の一部はほどよ く焦げて香気を生ずる。小麦粉だけをからいりして別に 脂肪を加えてもよいわけであるが，ルーにする方がスー プや牛乳に加えられたとき脂肪が乳化しやすく，また， バターのいため香もルー調理のし好性に関与しているこ とは味覚テストで明らかであった。

ルーを作る要点法弱火でゆっくり目的の温度にするこ とで, 火加減が強いとむらができてスープやソースにす るとき，まま粉になりやすい。加熱の最終温度はそれが 用いられる調理によって異なり, ホワイトソースには $130^{\circ} \mathrm{C}$ くらいまで, ブラウンソースには $150^{\circ} \mathrm{C}$ くらい までである。100ㄷ ではいための効果はあがらない。バ ターを用いたルーから抽出した脂肪の性状にはつぎのよ うな実験例がある。

表-3 ルーから分離したバターの性状

\begin{tabular}{c|c|c|r|r|c}
\hline $\begin{array}{c}\text { 加熱最終温度 } \\
\left({ }^{\circ} \mathrm{C}\right)\end{array}$ & $100^{(1)}$ & $130^{(1)}$ & $150^{(1)}$ & $150^{(2)}$ & $\begin{array}{c}\text { 対 照 } \\
\text { (butter } \\
\text { fat }\end{array}$ \\
\hline 加熱 時間 & $14^{\prime} 15^{\prime \prime}$ & $21^{\prime} 50^{\prime \prime}$ & $27^{\prime} 0^{\prime \prime}$ & $15^{\prime} 8^{\prime \prime}$ & 0 \\
A.V. & 0.7 & 0.7 & 0.7 & 0.7 & 0.7 \\
I.V. & 42.7 & 42.1 & 41.3 & 41.8 & 43.7 \\
粘 度 & 23.1 & 21.2 & 21.3 & - & 22.8 \\
\hline
\end{tabular}

- 測定しない

(1) ほ $300 \mathrm{~W}$ 電熱器使用

（2）注 $600 \mathrm{~W}$ 電熱器使用

\section{$2 \cdot 3$ 焼 き 物}

焼き物のらち油脂に関係あるものにビスケット（biscuit) やパイ (pie), シュー (choux)などがある。ビスケ ットは使用されるバターやショートニング，砂糖の量に よってかなり品質が違う。soft と呼ばれるものは脂肪や 砂糖の使用量が多く，口に入れると快く砕ける。これら の加熱は天火で静置状態で行なわれるから脂肪や砂糖が 多くても加熱中にくずれることはない。しかし，ショー

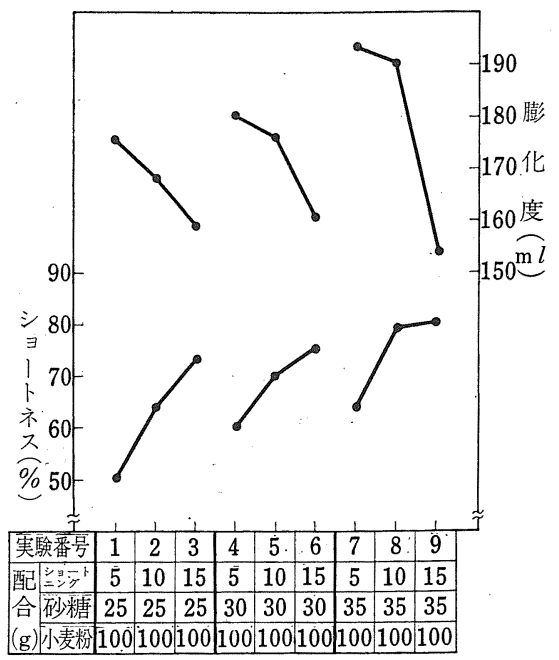

図-4 ビスケットの膨化度とショートネス

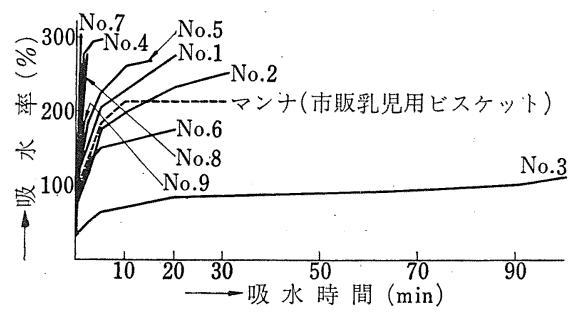

図-5 ビスケットの吸水速度

トネスの大きいものでは焼きたては天パンから持ち上げ るとくずれるから，天パンのままさまして脂肪の固まる のを待って取り扱う。

ビスケットについては竹林 ${ }^{8)}$ その他多くの報告がある

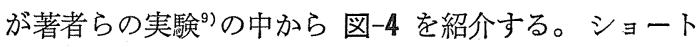
ネスは一定方法による製品の砕け分を全量に対する％ で示したもの，膨化度はナタネ法によった。また，これ らのビスケットにおける吸水速度は, 油脂の性質 3 によ り脂肪の多いものは遅い。しかし，一方における砂糖 の親水性に相殺されていることが図-5によってわか る。

シューについては竹林ら ${ }^{10)}$ の報告があり，できたシュ 一の成績評価を, 味, もろさ, 容積, 形状について行な っている。実験は油脂にはショートニングを $10,20 \mathrm{~g}$, 小麦粉は $15,21 \mathrm{~g}$ ，卵は $35,45 \mathrm{~g}$ ，水は $25,32 \mathrm{~g}$ とそれ ぞれ 2 段階の使用量として実験計画法により直交配列表 を用いて 16 組の実験を行なった結果，上の 4 評価のい ずれに対しても油脂の使用量が多いほど評価が高いとい らことである。

上の実験は常法(水とショートニングを沸騰させて,小 麦粉を大れ最後に卵を加えてよくまぜる) によったもの であるが，第 1 加熱の方法として小麦粉をバターでいた めてルーを作り，これに水を加えても温度において当を 


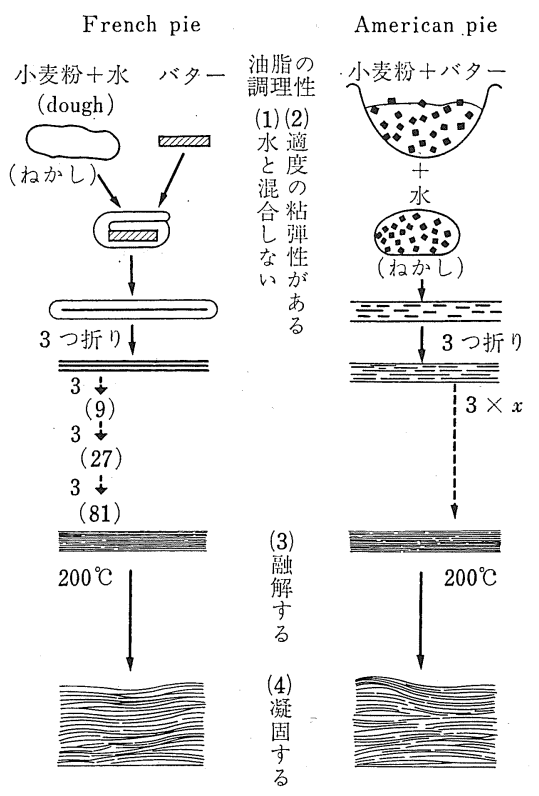

図-6 パイ作製の模式図

得るならば，第 2 加熱（天火で焼く）によって膨化し， シューを形づくることを得た ${ }^{11}$ 。

いずれにしてむ油脂がシューの膨化に対してはどのよ うな役割を果たしているかは明らかでない。一般にはバ ターやマーガリン,ショートニングなどが用いられるが。 中にいれるクリームのやわらかさとの調和からい光ば, これらの脂肪の一部を油に代えることが考えられる。実 際, サラダ油を加えて作るとやわらかいシューができる。 パイは 図-6 に示すように脂肪の諸性質が関連する興 味ある調理である。

図はパイクラスト製造過程を示す模式図で左列はフラ ンス式製法といわれるもので，小麦粉に水を加えてドウ を作り，これでバターを包んで延ばし，つぎに三つ折り にしてさらに延ばす。これを繰り返してしだいに層を増 し最後に $5 \mathrm{~mm}$ くらいの厚さにする。その間には脂肪層 は切れて連続しないところもできてくる。このようにし て作ったパイクラストを $200^{\circ} \mathrm{C}$ くらの天火で焼くと 脂肪はとけ，ドウに含まれた水の蒸気圧によってドウの 層は浮き上がる。浮き上がりをよくするためには，焼く 前のパイクラストの端は切り口にしておかなければなら ない。もし折り口であると，水蒸気の放出口がないから パイはきれいに浮かない。焼き上がったパイはさめると 脂肪はドウの薄層の上下で再び㠜固するが, 初めのなめ らかさはない。しかし，このことはパイのロざわりを悪 くはしない。パイのショートネスは薄層の積み重ねによ って得られるもので, スポンジ状のものとは趣きを異に する。右列はアメリカ式製法といわ机るものでバターは $1 \mathrm{~cm}$ 立方くらいに切られて粉と軽く混ぜられる。この 際のバターの大きさについては竹林 ${ }^{12}$ の研究があるが,
気温によって加減する必要があるであろう。つぎに水を 加えると水は小麦粉に吸収されてドウを作る。これを上 から押すとドウ中に点在する脂肪は扁平となって不連続 の薄層となる。その後はフレンチパイと同じ方法による が，折りたたみの回数は少なくてよいわけである。その 間に脂肪層は連続するところもでき, 結果としてフレン チパイと同じように焼き上がる。

パイ作りは気温が低く, 脂肪の融点が高い方がやさし い。夏は専門業者はのし板用金属板の下に氷を置いた り，低温室で作業をするが，家庭での解決策としては金 属製ののし棒の中に氷を入れたりする。

染野ら ${ }^{13}$ は練り込み法によるパイについて, 脂肪の種 類 (バター, マーガリン, パイバター,ショートニング, 豚脂)，使用量 (脂質として小麦粉の $45,70,90 \%$ ) を 変え, 加熱器として電気オーブン $\left(200^{\circ} \mathrm{C}, 15 \mathrm{~min}\right)$ と電

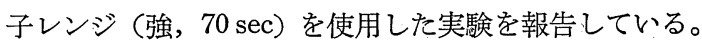
なお，できたパイの品質について膨化率，ショートネ ス，水分を測定し，総合してみるとパイバターが最も良 好であったという。また，脂肪の使用量は $70 \%$ 程度が よく, いずれの場合も電子レンジ加熱が電気オーブン加 熱よりもすぐれていたといらことである。ここに使われ たパイバターはほかの脂肪に比べて融点が最も高く（42 $\left.{ }^{\circ} \mathrm{C}\right)$ チュウ度も高いものであったといらことである。

アメリカ式製法では脂肪を小麦粉とともに手でもみほ ぐしながらよく混ぜる方法もある。この方法によると小 麦粉のグルテン形成は妨げられるから製品はビスケット におけるショートネスと似た結果になる。これは mealytype のもので pastry と呼ばれる。

小麦粉に対するこのような油脂の使い方はショートケ 一キを作る際の flour-batter 法 ${ }^{14)}$ 導き出しているもの で次図はその基礎的実験の結果を示す。

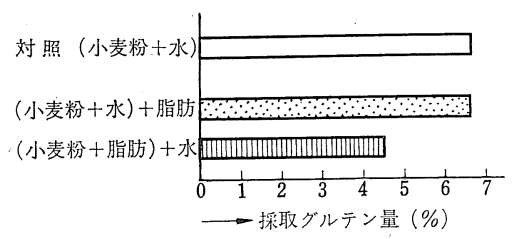

図-7 グルテン採取量（添加脂肪 30\%)

小麦粉に水を加えて作ったドウに脂肪を練り込んだも のからのグルテン採取量は対照と同じであるが，小麦粉 に脂肪を混ぜたのちに水を加えたドウからの採取グルテ ン量は少ないことがわかる。

以上のほかに，小麦粉を主材料とする焼き物に油脂を 使用する例は多い。表-4 ${ }^{16)}$ はそれらを一覧表にしたも ので，それぞれに対する油脂の効果はその調理性に基ゔ くものである。

なお，卵焼き，ホットケーキ，ワッフルなどを焼く場 合に用いられる油脂は，それが水を含まないこと，水と 
表-4 小麦粉を主原料とする焼き物の原料配合

\begin{tabular}{|c|c|c|c|c|c|}
\hline & 食パン & 菓子パン & シ゚ースト & パ & クッキー \\
\hline 小麦粉 & 100 & 100 & 100 & 100 & 100 \\
\hline 油 脂 & $2 \sim 4$ & $3 \sim 20$ & $20 \sim 60$ & $55 \sim 100$ & $20 \sim 50$ \\
\hline 砂 糖 & $0 \sim 5$ & $20 \sim 30$ & $10 \sim 20$ & - & $30 \sim 60$ \\
\hline 卵 & - & - & $5 \sim 40$ & $20 \sim 30$ & $0 \sim 50$ \\
\hline \multirow[t]{2}{*}{ 水 } & $40 \sim 60$ & $40 \sim 60$ & $20 \sim 60$ & $5 \sim 90$ & $0 \sim 50$ \\
\hline & クラッカー & $\begin{array}{l}\text { パウンド } \\
\text { ケーキ }\end{array}$ & 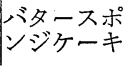 & バーム & ドーナツ \\
\hline 小麦粉 & 100 & 100 & 100 & 100 & 100 \\
\hline 油 脂 & $5 \sim 15$ & $30 \sim 100$ & $5 \sim 30$ & $80 \sim 100$ & $0 \sim 30$ \\
\hline 砂 糖 & - & $50 \sim 100$ & $90 \sim 150$ & $80 \sim 100$ & $30 \sim 40$ \\
\hline 卵 & - & $50 \sim 100$ & $100 \sim 200$ & $150 \sim 220$ & $5 \sim 50$ \\
\hline 水 & $30 \sim 60$ & $0 \sim 50$ & $20 \sim 50$ & $0 \sim 50$ & $10 \sim 60$ \\
\hline
\end{tabular}

混じらないことなどのために，食品が加熱器に付着する のを防ぐ。その他，種々のソテーやムニエルの場合には 同時に食品に油脂味をつけることもあるので, 焼くのに はサラダ油を用いて，焼き上がりのころにバターを追加 することが多い。

\section{$2 \cdot 4$ 油脂を生のまま用いる調理}

この調理には主として油脂の調理性 $3,4,6,8$ が関 与する。とくに 8 はこの調理のし好性を左右する要因と なるところである。

マヨネーズソースの主原料の一つである卵黄がすでに 水中油滴型のエマルションであるから，油と酢でこれを 増大寸ることがマヨネーズ作りの要点である。加えられ る調味料や香辛料は乳化に際してプラスに働いたり，マ イナスに㗢いたりする。中でもカラシはかなり強い乳化 力をもっているよらであるが，塩やコショウはこれに反 する。マヨネーズについての研究報告はかなり多くある が，そのうち，戸井 ${ }^{17)}$ ，太田ら ${ }^{18)}$ の報告は小規模にマヨ ネーズを作る場合にも参考になることが多いと思う。そ れによると，1）油が多いほど粘性が高く，マヨネーズ の粘性はまた，使われた油の粘性の影響を受ける。2)

油をゆっくり加えるほど製品の粘度は高い。油がゆっく り加えられれば分散する油の粒形が小さくなるからであ ろう。3）油の種類によってマヨネーズのかたさは多少 違うが油の種類によるマヨネーズの安定性の違いは認め られないなどである。

フレンチソースは酢油ソースといわれるもので, 酢, 油，食塩を基調とし香辛料は好みによる。酢，油の割合

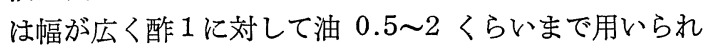
る。乳化剤が加わらないから二層に分離する。これを食 卓でよく振り混ぜて使うのが常法となっているが，カラ シを乳化剈として充分かくはんするとマヨネーズソース のような状態になる。また, 酸味剤としてレモンを使う と一層乳化しやすい" ${ }^{19)}$ 。レモンに含まれるペクチンが乳 化に預かっているものと考えられる。
最近ではこれにも乳化肪を用いてエマルションとした 製品がドレッシングの名で販売されている。これらはい ずれも W/O 型である。マヨネーズとドレッシングの水 分と油の含量は 表-6 のよらであるが, 食味的にはマヨ ネーズの方が淡白で油味を直接感ずることが少ないのは エマルションの型の違いであろら。実際マヨネーズに使 った器はフレンチソースのそれよりも洗いやすい（表 -6参照)。

調理に際して食塩, 酢, 油の使用順序が野菜からの浸 出液の量に関係あることについての実験 ${ }^{20)}$ がある。それ によると最初に油で食品の表面をおおえば，浸出液は少 ない。

調味用の菻油 (マユ) は古くから中華料理に用いられ るかおり高いゴマ油である。涼拌 (リャンパン) 料理 (冷たいあえもの) の仕上げに，また，餃子(チャオツ) (ぎょうざ) の付け汁などに生のまま加えられる。ゴマ の香気をこれだけ残すためには精製度は低く，色も淡力

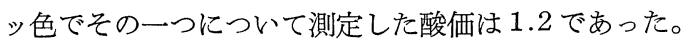
この点同じ生食用でもサラダ油とは大いに違ら。油の生 食用目的のまったく違ら面を表わしているものである。

生クリームのホイップ (whip) 用は $35 \sim 40 \%$ の 脂肪が含まれている。適度にアワ立てると $\mathrm{O} / \mathrm{W} の$ エマルションのままで空気を含み，しだいに軽く なってかたくなる。ケーキのデコレーションとして 適当なかたさのときのオーバーラン (over-run) $\left(\frac{\text { 生クリーム } 100 \mathrm{~m} l \text { の重さーアワ立てクリーム } 100 \mathrm{~m} l \text { の重さ } \times 100}{\text { アワ立てクリーム } 100 \mathrm{~m} l \text { の重さ }}\right)$ は 必ずしも一定ではない。これに関与する条件としては， 生クリームの脂質含量, 製造に際しての, また, その後 の温度履歴, ホイップ時の試料温度, かくはん方法など が考えられる。これらの点が調理上の問題点で, とかく， デコレーションとしての最適状態を見逃しやすく，ホエ イ (whey) が分離し始めてアワ立器に脂肪がバター状に 付着する。脂肪は初めアワ粒大でしだいに豆粒大になり， 遂には一塊のバターとなる。こうなったものは徐々に温 度を上げながらかくはんすると，やや流動性を生じてな めらかになるから，これに分離したホエイを少しずつ加 えてかくはんしながら全量を大れ終わると，マヨネーズ に似た外観になる。これをかくはんしてももはやオーバ ーランは前のように大きくならず，ホエイも分離しな い。これも砂糖を加えればデコレーションに使えないこ とはないが，このものは W/O 型であるから黄色味が濃 く, ホイップクリームのロざわりとはまったく違って油 濃いものである。これも冷せばかくはんによってふたた びホエイを分離するが，もとの生クリームには直らな い。は 表-5 茶せん型アワ立器で手動かくはんによる実 験 ${ }^{21)} ゙$ あが，上に述べた一連の操作と生クリームの状 態のおよその変化の傾向を示している。

最近の生クリームはホイップ効果の調整のためにほか 
表-5 操作温度によるアワ立てクリームの性状

\begin{tabular}{|c|c|c|c|c|c|c|c|c|c|}
\hline \multirow{2}{*}{ 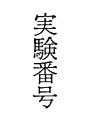 } & \multicolumn{3}{|c|}{$15^{\circ} \mathrm{C}$} & \multicolumn{3}{|c|}{$10^{\circ} \mathrm{C}$} & \multicolumn{3}{|c|}{$5^{\circ} \mathrm{C}$} \\
\hline & $\begin{array}{l}\text { アワ立時間 } \\
\text { (min. sec) }\end{array}$ & $\mid \begin{array}{c}\text { オーバーラン } \\
(\%)\end{array}$ & $\begin{array}{l}\text { ゼリー強度 } \\
\left(\text { dyn } / \mathrm{cm}^{2}\right)\end{array}$ & $\begin{array}{l}\text { アワ立時間 } \\
\text { (min. sec) }\end{array}$ & $\mid \begin{array}{c}\text { オーバーラン } \\
(\%)\end{array}$ & $\begin{array}{l}\text { ゼリー強度 } \\
\left(\mathrm{dyn} / \mathrm{cm}^{2}\right)\end{array}$ & $\begin{array}{l}\text { アワ立時間 } \\
\text { (min. sec) }\end{array}$ & $\begin{array}{c}\text { オーバーラン } \\
(\%)\end{array}$ & $\begin{array}{l}\text { ゼリー強度 } \\
\left(\mathrm{dyn} / \mathrm{cm}^{2}\right)\end{array}$ \\
\hline 1 & 7.30 & 70 & $10 \times 10^{3}$ & 15.50 & 119 & $9 \times 10^{3}$ & 17.00 & 117 & $5 \times 10^{3}$ \\
\hline 2 & 3.15 & 52 & 12 & 8.00 & 106 & 9 & 11.30 & 111 & 4 \\
\hline 3 & 4.25 & 50 & 13 & 11.55 & 99 & 10 & 15.25 & 115 & 7 \\
\hline 4 & 4.30 & 67 & 11 & 11.10 & 117 & 6 & 10.00 & 137 & 4 \\
\hline 5 & 5.35 & 68 & 10 & 8.30 & 107 & 5 & 9.40 & 109 & 5 \\
\hline 6 & 8.25 & 55 & 10 & 12.40 & 114 & 6 & 14.10 & 114 & 5 \\
\hline 7 & 8.10 & 60 & 13 & 18.10 & 122 & 6 & 14.30 & 112 & 6 \\
\hline 8 & 8.40 & 69 & 9 & & & & 15.25 & 130 & 6 \\
\hline 平 均 & 6.19 & 61 & 11 & 12.19 & 112 & 7 & 13.28 & 118 & 5 \\
\hline
\end{tabular}

の油脂や乳化剤を加えたものもあると聞いている。ま た，ホイップ用として市販されている粉末クリームもあ る。

ショートニングオイルは揚げ物や焼き製品など用途は 広いが，ここでは生で食用にされるデコレーション用と してのショートニングについて記す。この用途には融点 の比較的低い，空気または窒素の含まれているショート ニングが用いられる。生クリームのもつすぐれた風味は ないが, 無味, 無臭, 白色であることは, 好みの香料を 用いたり，ひき茶，ニッケイ粉その他の色付けをきれい にする。また, 細かい飾りがはっきり表現できるのはシ ョートニングのこの用途としての長所である。

ショートニングは水分を含まないから，これをデコレ ーション用にホイップするに際し，いかにして水分を加 えるかが要点であろら。加えられる砂糖をシロップにし ておくのも一方法であり, また, 卵白を併用する方法も ある。それにしても製品は W/O 型であるから，O/W 型で水分を $50 \%$ 以上も含む生クリームのホイップした ものに比べて油濃いことは免れない。この点がショート ニングによるこの用途としての難点である。 $\mathrm{O} / \mathrm{W}$ 型の 液状ショートニングも業務用としては作られているとい うことではある。

ケーキのデコレーションの上に一滴の水または油を置 いてみることで，使用されている油脂のエマルションの 型はわかる。

\section{3 食品の油脂含量とテクスチュア (texture)}

日常私どもが口にしている食品の中には同種のもので も油脂含量によってテクスチュアの違うものがある。次 表のらち，ビスケットからアイスクリームまでは油脂含 量が多いほど一般には好まれ，高級品と考えられている もので, 油脂味そのものといらよりはそのクリーミング 性, ショートニング性, 融解温度などの, テクスチュア に対する効果という方が適切のように思う。

ドレッシングとマヨネーズについてはすでに述べたと おりである。フレンチポテトとポテトチップのテクスチ
表-6 食品の油脂含量と texture

\begin{tabular}{|c|c|c|c|}
\hline 食 品 名 & 水分 $(\%)$ & 脂質 $(\%)$ & 備 \\
\hline ハードビスケット & $\begin{array}{l}4.8 \\
4.8\end{array}$ & $\begin{array}{r}8.2 \\
17.0\end{array}$ & \\
\hline $\begin{array}{l}\text { ス゚ンジケーキ } \\
\text { バターケーキ }\end{array}$ & $\begin{array}{l}40.8 \\
33.0\end{array}$ & $\begin{array}{r}5.1 \\
14.1\end{array}$ & 原料割合 \\
\hline 魚肉ソーセージ $\underset{B}{\mathrm{~A}}$ & $\begin{array}{l}67.3 \\
64.8\end{array}$ & $\begin{array}{r}6.5 \\
12.6\end{array}$ & 一般市販品 \\
\hline $\begin{array}{c}\text { アイスクリーム(低脂) } \\
\text { " (高脂) }\end{array}$ & $\begin{array}{l}68.0 \\
65.0\end{array}$ & $\begin{array}{l}3.5 \\
8.5\end{array}$ & \\
\hline 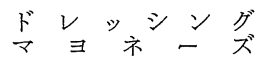 & $\begin{array}{l}53.5 \\
23.0\end{array}$ & $\begin{array}{l}42.1 \\
70.0\end{array}$ & \\
\hline $\begin{array}{l}\text { プレンチポテト } \\
\text { ポテレッチ }\end{array}$ & $\begin{array}{r}31.0 \\
4.2\end{array}$ & $\begin{array}{r}5.5 \\
43.8\end{array}$ & \\
\hline 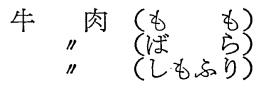 & $\begin{array}{l}71.6 \\
60.9 \\
45.6\end{array}$ & $\begin{array}{r}6.1 \\
20.5 \\
41.0\end{array}$ & \multirow{2}{*}{ 天然食品 } \\
\hline 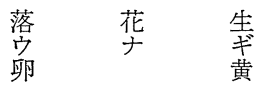 & $\begin{array}{r}7.6 \\
60.7 \\
49.5\end{array}$ & $\begin{array}{l}46.6 \\
18.0 \\
32.5\end{array}$ & \\
\hline
\end{tabular}

ユアの差は油脂含量といらよりは水分の違いによる方が 大きい。

一般に食品中の油脂含量と水分とは大小相反するもの であるからテクスチュアへの影響は両者によるものと考 えなければならない。牛肉以下は天然食品で牛肉の脂肪 41\%も，それがしもふりであればこそすき焼きなどでお いしく食べられるが，この量がまとまって存在したらお そらく牛脂用になるであろら。落花生やウナギ，卵黄は それぞれ別の成分や組織から成るものであるから，ほか の食品のように油脂と水分だけを論ずることはできな い。ここにあげたのはこの三者では油脂含量と口当たり の上からの油濃さとは逆に感ずるのではないか，そし て，それは油脂の種類やあり方とほかの成分との複雑な 結合の結果と考えられる。つまり，天然物中にある油脂 は必ずしも油脂の性質を露出しないといら初めの記述に もどる。

本稿は昭和 43 年 6 月日本油化学協会主催第 2 回油と調理に関 する談話会の談話に加筆したものである。 


\section{（昭和 43 年 9 月 19 日受理） \\ 文 献}

1）松元，大武，家政学雑誌，8，156 (1957)

2) 太田, 妻鹿, 渋江, 油化学, 15, 533 (1966)

3）島田, 家政学雑誌，17，391 (1966)

4) 関, 松元, 家政学雑誌投稿中

5）安松, 武田研究所年報, 26, 206 (1967)

6) 矢崎, 浪花, 郷, 食, 8 (6), 1 (1962)

7) 渡部, 新垣, 島田, 松元, 日本家政学会第 19 回総会で講 演

8) 竹林, 福井大学学芸学部紀要, 2, 10-3 集 (1960)

9) 松元, 中村, 新野, 家政学雑誌, 9, 14 (1958)

10）小林, 竹林, 家政学雑誌, 19, 269 (1968)

11）阿部，松元，家政学雑誌，15，245 (1964)
12) 竹林, 東京都立川短大紀要 (1962)

13）染野，手塚，川又，食生活，3月，162（1968）；同誌， 4月, 157 (1968)

14) Belle Lowe, Experimetal Cookery, p. 471 (1959)

15）松元，比留間，家政学雑誌，12，455 (1961)

16) 松井, 日本油化学協会主催第 2 回油と調理に関する談話 会講演資料 (1968，6 月)

17）戸井，太田，鈴木，家政学雑誌，13，1 (1962)

18）太田, 高山, 家政学雑誌, 14, 167 (1963)

19）松元，林，家政学雑誌，8，265 (1957)

20）直井, 女子栄養大学, 未発表

21）森井，松元，お茶 の水女子大学家政学部卒業論文発表要 旨, p. 2 (昭和 42.2 .28 )

\section{統計}

昭 和 42 年 油 脂, 油脂原料輸出実績

\begin{tabular}{|c|c|c|c|c|c|}
\hline & 数 量 $(t)$ & 金 額（千円） & & 数 量 $(t)$ & 金 額 (千円) \\
\hline - $\quad$ r & 1,617 & 146,466 & パーム核 油 & 950 & 92,969 \\
\hline 豚 脂 & 327 & 27,205 & ヒ マ シ 油 & 9,992 & $1,052,405$ \\
\hline 牛脂. 家き乙脂 & 299 & 26,894 & ב゙ マ 油 & 722 & 161,298 \\
\hline 魚油 & 2,134 & 163,010 & 植 物 性 油 脂 & 420 & 60,463 \\
\hline ナガス 鯨 油 & 39,528 & $2,262,345$ & 動 物 性 油 脂 & 111 & 27,013 \\
\hline マッコウ鯨 油 & 13,518 & 679,906 & 計 & 85,273 & $6,269,062$ \\
\hline 大 豆 油 & 5,020 & 506,434 & & & \\
\hline 綿 実 油 & 17 & 3,326 & 落 & - & 93 \\
\hline 落 花 生 油 & 469 & 59,315 & 豆 & 746 & 38,202 \\
\hline オ リ ブ 油 & 5 & 1,730 & シ & 2 & 72 \\
\hline ナタネ油, カラシ油 & 9,500 & 926,793 & 綿 & 1 & 163 \\
\hline$\checkmark \nabla=$ 油 & 521 & 56,156 & ت゙ $\quad \nabla$ & 7 & 5,421 \\
\hline パーム 油 & 58 & 5,801 & 採油用種 実 & 1 & 41 \\
\hline$ヤ \quad$ シ 油 & 65 & 9,533 & 計 & 757 & 43,992 \\
\hline
\end{tabular}

（日本油脂工業会年報）

（野中正夫） 